\title{
坚持原创导向 在新时代做新贡献
}

转眼之间, 陈嘉庚科学奖已经设立 15 年了. 15 年前, 秉承陈嘉庚先生爱国兴学、服务人民的崇高精 神, 在国务院的直接关怀下, 中国科学院和中国银 行携手合作, 在原陈嘉庚奖的基础上, 设立了陈嘉 庚科学奖, 奖励在中国做出的重大原创性科学技术 成果. 2010 年, 我们又设立了陈嘉庚青年科学奖, 奖 励在中国独立做出重要原创性科学技术成果的青年 科技人才. 15 年来, 陈嘉庚科学奖依托中国科学院 学部平台, 先后评选了 30 项陈嘉庚科学奖获奖项目

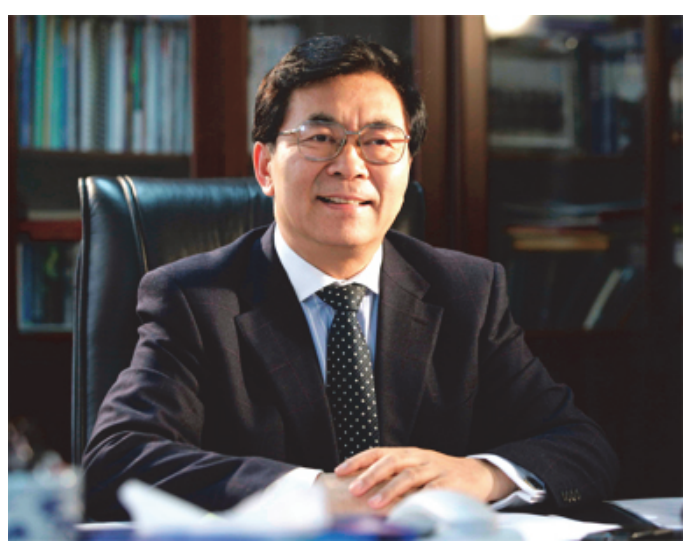

白春礼 和 22 位陈嘉庚青年科学奖获奖人, 影响力不断提高, 已经成为我国重要的科技奖项之一.

坚持原创导向是陈嘉庚科学奖和青年科学奖最为突出的特征. 我们希望奖励我国的原 始性创新成果，激励广大科技工作者瞄准世界科技前沿，强化基础研究，实现前瞻性基础研 究、引领性原创成果重大突破. 2018 年度陈嘉庚科学奖 6 项获奖成果很好地体现了陈嘉庚科 学奖鼓励原创的理念，比如高鸿钧研究员为原子尺度上“小分子机器”在固体表面的构筑与 物性调控研究做出了重要贡献; 包信和教授提出“纳米限域催化”概念并实现了甲烷分子的 高选择性转化; 李家洋研究员发现与阐明了控制水稻株型发育的关键基因及其调控机制; 戴金星研究员创立的煤成气理论体系为我国大型煤成气田的发现做出了重大贡献; 徐宗本 教授和吴一戎研究员提出的 $L_{1 / 2}$ 正则化方法对稀疏信号处理具有重要的理论意义和应用价 值; 田永君教授合成出比天然金刚石更硬的人工材料.

在科技创新中最重要的因素是人，而青年人才是科研工作的中坚力量，是我国科技创新 的未来与希望。陈嘉庚青年科学奖是专门为青年科技人才而设立的，希望鼓励和支持更多 的青年人献身科技事业. 2018 年度陈嘉庚青年科学奖的 6 位获奖者都在各自的研究领域内 取得了可喜的成绩, 江颖在实验中发现了水分子中氢键的核量子效应; 黄正发展了新型催 化剂, 为烷烃至烯烃、烷基硅的高效转化以及聚乙烯废塑料的绿色转化提供了科学依据; 吴 蓓丽解析了 6 种与重要疾病药物研发相关的 $\mathrm{G}$ 蛋白偶联受体的晶体结构; 孙业乐在大气复 
合污染研究方面做出了原创性成果, 为京津冀大气污染防治做出了重要贡献; 常超提出的 超高功率微波窗模型与方法具有重要的理论意义和应用价值; 朱嘉发明了低成本高效率太 阳能光热转换材料及其海水淡化装置.

中国特色社会主义已进入新时代, 我国经济社会发展也已经进入了必须依靠创新驱动 才能持续发展的新阶段, 这是科技创新地位和作用更加凸显的时代, 是科技工作者大显身 手的时代. 让我们按照党的十九大部署, 以习近平新时代中国特色社会主义思想为指导, 牢 记服务国家造福人民的初心，担当起科技创新的崇高使命，为决胜全面建成小康社会，加快 推动创新型国家和世界科技强国建设做出新的更大贡献.

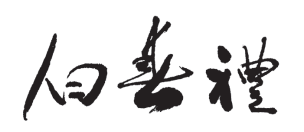

中国科学院院长 中国科学院学部主席团执行主席 陈嘉庚科学奖基金会理事长 